\title{
LIGNINOLYTIC ENZYME SYSTEM IN ECOLOGICAL ADAPTATION OF LIGNICOLOUS MACROFUNGI
}

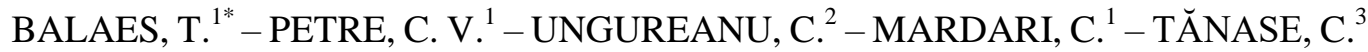 \\ ${ }^{I}$ Anastasie Fatu Botanical Garden, Alexandru Ioan Cuza University of Iasi \\ Dumbrava Rosie 7-9, 700487, Iasi, Romania \\ ${ }^{2}$ Dunarea de Jos University, Faculty of Food Science and Engineering \\ 47 Domneasca St., 800008 Galati, Romania \\ ${ }^{3}$ Faculty of Biology, Alexandru Ioan Cuza University of Iasi \\ Carol I 20A, 700505, Iasi, Romania \\ *Corresponding author \\ e-mail: tiberius.balaes@gmail.com; phone:+40749789156 \\ (Received $13^{\text {th }}$ Aug 2016; accepted $10^{\text {th }}$ Oct 2016)
}

\begin{abstract}
Lignicolous macrofungi are the most important group of wood decomposers. Among the enzymes involved in wood decomposition, ligninases play an important role in this process and species that produce those enzymes degrade both cellulose and lignin. In this study we hypothesized that ligninases are influencing the ecological success of lignicolous macrofungi. Three hypotheses have been tested: $\mathrm{h} 1$ - the species producing several types of ligninases have a broader spectrum of hosts / substrates; $\mathrm{h} 2$ - the obligate saprotrophic species have a greater potential in degrading lignin and related compounds than the other groups; and $\mathrm{h} 3$ - the frequencies of lignicolous species is related to the production of highly active enzymes. Scientific data compiled from literature and completed with our own experimental results have been statistically interpreted using XLStat and MaxLite Software. Our results confirm the first two hypotheses, proving that ligninases play a direct role in colonizing a wide range of wood types, with chemical particularities. The third hypothesis should be rejected as no correlation has been observed. The present study offers new insights into ecological meanings of ligninases, and is the first attempt to connect the ligninolytic enzyme system to host range.
\end{abstract}

Keywords: ligninases, wood decomposers, lignin degradation, white-rot fungi, laccases

\section{Introduction}

Lignicolous macrofungi form a large group of fungi involved in the degradation of wood, with remarkable adaptations to different ecological niches.

Saprotrophic, parasitic or sapro-parasitic lignicolous macrofungi possess different strategies for colonizing wood and using it as a substrate and a source of nutrients. Depending on their ecology and type of nutrition, these species decay the wood, decomposing cellulose, hemicelluloses and sometimes lignin, which is one of the most abundant biomacromolecule on Earth (Knežević et al., 2013). Degradation of lignin might offer fungi advantages such as eliminating the barrier for the degradation of cellulose and increasing the availability of nitrogen in a substrate with a very high $\mathrm{C}: \mathrm{N}$ ratio, through degradation of other wood constituents (Deacon, 2006).

This study is aimed at testing if the number of ligninases produced is influencing the spectrum of substrate / wood type / hosts, thus having ecological meanings. For this purpose three hypothesis have been formulated: h1 - the species producing several types of ligninases are able to colonize more types of wood compared to the species that produce a smaller number of ligninases; h2 - the obligate saprotrophic species (OS) 
have a greater potential in degrading wood (by degrading lignin) than sapro-parasitic (SP) and obligate parasitic species (OP); and h3 - competitive species produce highly active enzymes. To test these hypothesis data concerning the types of substrata, ligninase production and enzyme activity, for 69 lignicolous basidiomycetes, have been collected from literature and completed with personal experimental results.

Our interpretation suggests that there is a positive correlation between the number of ligninases and the number of hosts and OS are better wood decomposers, while the third hypothesis should be rejected. These findings offer new insights over the biochemical adaptation for colonizing a substratum with particular ecological characteristics such as wood. From our knowledge, this is the first study trying to search possible directly connections between the ligninolytic enzyme system and host range of lignicolous macrofungi.

\section{Review of Literature}

Wood decay takes place trough different biochemical mechanisms, and three types of rot can occur: $\mathrm{a}$ - soft rot, when fungi produce cellulases and $\mathrm{H}_{2} \mathrm{O}_{2} ; \mathrm{b}$ - brown rot, when a cellulolytic enzyme system is involved and the cellulose / hemicelluloses are degraded while the lignin persists in the wood giving it a characteristic brown color; and c- white rot, in this case cellulose / hemicelluloses and lignin are degraded by particular enzymes. The concept of classifying wood rot is currently in revision, as some species "mimic" the white rot production (Nagy et al., 2015).

Ligninases are enzymes that produce the breakdown of lignin during wood decay. These enzymes play an important role in the nutrition of lignicolous fungi, frequently associated and acting synergistically.

There are several types of ligninases, and a particular species of macrofungi might produce one, few or all types. Many species produce two or three isomorphs of the same enzyme. The most common type of ligninases is represented by laccases, described for a large number of lignicolous macrofungi, including the ones that produce brown rot although the synthesis of laccases have been recorded in this cases as traces.

The occurrence of laccases (EC 1.10.3.2) and their role in the ecology of lignicolous fungi have been reviewed by several authors (Baldrian, 2006; Valderrama et al., 2003). Other common ligninases are Lignin Peroxidase-LiP (E.C. 1.11.1.14), Manganese dependent Peroxidase-MnP (E.C. 1.11.1.13), Manganese Independent Peroxidase-MIP (EC 1.11.1.16), while less frequent are Aryl Alcohol Oxidase-AAO, Versatile Peroxidase-VP, Dye-degrading Peroxidase-DyP (Anastasi et al., 2010; Grąz and JaroszWilkołazka, 2011; Palmieri et al., 2005). In an extensive study involving the screening of genes encoding ligninases in a broad sense, Nagy and collaborators (2015) suggest that in the degradation of lignin, a much larger group of ligninases is involved, although some classes of enzymes play a secondary role. The production of a particular ligninase vary largely from one species to another in terms of amounts and the enzyme activity and the required conditions as well.

\section{Materials and Methods}

The available literature has been reviewed in order to collect information regarding the host's spectrum, number of ligninases produced, frequency of species, type of nutrition and the efficiency of ligninolytic enzyme system for 69 species of lignicolous basidiomycetes. Most of the species listed in Table 1 have also been isolated and stored 
in our laboratory collection. When data were missing from literature for particular species, the information has been completed with experimental data.

Table 1. List of investigated species of macrofungi, their enzymatic properties, ecological features and data source (NE - number of enzymes, EA - enzyme activity, DE - dye degradation efficiency, $\mathrm{CH}$ - common host genera - TH, F-frequency, NT - nutrition type)

\begin{tabular}{|c|c|c|c|c|c|c|c|c|}
\hline Species & NE & EA & DE & CH & TH & $\mathbf{F}$ & NT & References \\
\hline $\begin{array}{l}\text { Abortiporus } \\
\text { biennis }\end{array}$ & 3 & 3 & 4 & 18 & 26 & 1 & OS & $\begin{array}{l}\text { Aggelis et al., 2002; ARS; Bernicchia, } \\
\text { 2005; Casieri et al., 2010; Ryvarden and } \\
\text { Gilbertson, } 1993\end{array}$ \\
\hline $\begin{array}{l}\text { Armillaria } \\
\text { mellea }\end{array}$ & 3 & 3 & 1 & 9 & 82 & 2 & $\mathrm{OP}$ & $\begin{array}{l}\text { Balaeş et al., 2013; Casieri et al., 2010; } \\
\text { Diamandis and Perlerou, 2001; } \\
\text { Matsushita and Suzuki, 2005; Stoytchev } \\
\text { and Nerud, 2000; Otieno et al., 2003; } \\
\text { PKB; Qin et al., 2007; Szczepkowsk, } \\
2007\end{array}$ \\
\hline $\begin{array}{l}\text { Auricularia } \\
\text { auricula-judae }\end{array}$ & 4 & 4 & 1 & 2 & 24 & 2 & OS & $\begin{array}{l}\text { ARS; Balaess et al., 2013; Liers et al., } \\
\text { 2010; Negrean and Anastasiu, } 2004\end{array}$ \\
\hline $\begin{array}{l}\text { Bjerkandera } \\
\text { adusta }\end{array}$ & 6 & 7 & 5 & 25 & 32 & 2 & OS & $\begin{array}{l}\text { Anastasi et al., 2010; Balaeş et al., 2013; } \\
\text { Balaeș and Tănase, 2013; Bernicchia, } \\
\text { 2005; Eichlerova et al., 2006a; Erkkilâa } \\
\text { and Niemelâ, 1986; Guillén et al., 2011; } \\
\text { Robinson and Nigam, 2008; Ryvarden } \\
\text { and Gilbertson, 1993; Tinoco et al., 2007 }\end{array}$ \\
\hline $\begin{array}{l}\text { Bjerkandera } \\
\text { fumosa }\end{array}$ & 1 & 1 & 3 & 15 & 20 & 1 & OS & $\begin{array}{l}\text { ARS; Balaeş et al., 2013; Bernicchia, } \\
\text { 2005; Graz and Jarosz-Wilkolazka 2011; } \\
\text { Ryvarden and Gilbertson, } 1993\end{array}$ \\
\hline $\begin{array}{l}\text { Cerrena } \\
\text { unicolor }\end{array}$ & 4 & 4 & 4 & 17 & 21 & 2 & OS & $\begin{array}{l}\text { Bernicchia, 2005; Elisashvili et al., 2010; } \\
\text { Erkkilâ and Niemelâ, 1986; Hattori, 2005; } \\
\text { Ranadive et al., 2011; Souza-Ticlo et al., } \\
2009\end{array}$ \\
\hline $\begin{array}{l}\text { Coriolopsis } \\
\text { gallica }\end{array}$ & 2 & 2 & 4 & 2 & 20 & 2 & SP & $\begin{array}{l}\text { ARS; Balaeș et al., 2013; Bernicchia, } \\
\text { 2005; Hansent and Knudsen, 1997; } \\
\text { Robinson et al., 2001; Ryvarden and } \\
\text { Gilbertson, } 1993\end{array}$ \\
\hline $\begin{array}{l}\text { Cyathus } \\
\text { striatus }\end{array}$ & 1 & 1 & 2 & 1 & 3 & 2 & OS & $\begin{array}{l}\text { ARS; Balaeş et al., 2013; Casieri et al., } \\
2010\end{array}$ \\
\hline $\begin{array}{l}\text { Daedalea } \\
\text { quercina }\end{array}$ & 2 & 2 & 1 & 1 & 15 & 2 & OS & $\begin{array}{l}\text { Balaeş et al., 2013; Baldrian 2004; } \\
\text { Bernicchia, 2005; Ranadive et al., 2011; } \\
\text { Ryvarden and Gilbertson, } 1993\end{array}$ \\
\hline $\begin{array}{l}\text { Daedaleopsis } \\
\text { confragosa }\end{array}$ & 1 & 1 & 1 & 1 & 19 & 2 & SP & $\begin{array}{l}\text { Balaeş et al., 2013; Bernicchia, 2005; } \\
\text { Erkkilâ and Niemelâ, 1986; Orth et al., } \\
\text { 1993; Ranadive et al., 2011; Ryvarden } \\
\text { and Gilbertson, } 1993\end{array}$ \\
\hline $\begin{array}{l}\text { Datronia } \\
\text { caperata }\end{array}$ & 1 & 1 & 3 & 1 & 3 & 1 & SP & $\begin{array}{l}\text { Abrahao et al., 2008; ARS; Gilbert and } \\
\text { Sousa, 2002; Minter et al., } 2001\end{array}$ \\
\hline $\begin{array}{l}\text { Dichomitus } \\
\text { squalens }\end{array}$ & 6 & 5 & 5 & 2 & 7 & 1 & OS & $\begin{array}{l}\text { Aggelis et al., 2002; ARS; Bernicchia, } \\
\text { 2005; Eichlerova et al., 2006c; Novotný et } \\
\text { al., 2012; Orth et al., 1993; Ryvarden and } \\
\text { Gilbertson, 1993; Šušla et al., } 2007\end{array}$ \\
\hline $\begin{array}{l}\text { Flammulina } \\
\text { velutipes }\end{array}$ & 1 & 1 & 2 & 2 & 16 & 2 & OS & $\begin{array}{l}\text { ARS; Balaeş et al., 2013; Eichlerova et } \\
\text { al., 2006a; Gerault, 2005; Petersen et al., } \\
\text { 1999; Szczepkowski, } 2007\end{array}$ \\
\hline
\end{tabular}




\begin{tabular}{|c|c|c|c|c|c|c|c|c|}
\hline $\begin{array}{l}\text { Fomes } \\
\text { fomentarius }\end{array}$ & 2 & 2 & 2 & 3 & 18 & 2 & SP & $\begin{array}{l}\text { Balaeş et al., 2013; Bernicchia, 2005; } \\
\text { Casieri et al., 2010; Elisashvili et al., } \\
\text { 2009; Erkkilâ and Niemelâ, 1986; } \\
\text { Ryvarden and Gilbertson, } 1993\end{array}$ \\
\hline $\begin{array}{l}\text { Fomitopsis } \\
\text { pinicola }\end{array}$ & 1 & 1 & 1 & 5 & 23 & 2 & SP & $\begin{array}{l}\text { Balaeş et al., 2013; Casieri et al., 2010; } \\
\text { Erkkilâ and Niemelâ, 1986; Hattori, 2005; } \\
\text { Ryvarden and Gilbertson, } 1993\end{array}$ \\
\hline $\begin{array}{l}\text { Ganoderma } \\
\text { adspersum }\end{array}$ & 1 & 1 & 3 & 1 & 9 & 2 & OP & $\begin{array}{l}\text { ARS; Balaeş et al., 2013; De Simone and } \\
\text { Annesi, 2012; Elisashvili and Kachlishvili } \\
2009\end{array}$ \\
\hline $\begin{array}{l}\text { Ganoderma } \\
\text { applanatum }\end{array}$ & 2 & 2 & 2 & 9 & 53 & 2 & SP & $\begin{array}{l}\text { Balaeş et al., 2013; Bernicchia, 2005; } \\
\text { Casieri et al., 2010; Elisashvili and } \\
\text { Kachlishvili 2009; Elisashvili et al., 2009; } \\
\text { Erkkilâ and Niemelâ, 1986; Levin et al., } \\
\text { 2004; Ryvarden and Gilbertson, 1993; } \\
\text { Sankaran et al., 2005; SIPMP; } \\
\text { Szczepkowski, } 2007\end{array}$ \\
\hline $\begin{array}{l}\text { Ganoderma } \\
\text { lucidum }\end{array}$ & 4 & 4 & 2 & 13 & 45 & 2 & OS & $\begin{array}{l}\text { Asgher et al., 2010; Balaes et al., 2013; } \\
\text { Bernicchia, 2005; Elisashvili and } \\
\text { Kachlishvili 2009; Erkkilâ and Niemelâ, } \\
\text { 1986; Orth et al., 1993; Ranadive et al,, } \\
\text { 2011; Ryvarden and Gilbertson, 1993; } \\
\text { Sankaran et al., 2005; SIPMP }\end{array}$ \\
\hline $\begin{array}{l}\text { Ganoderma } \\
\text { resinaceum }\end{array}$ & 1 & 1 & 3 & 1 & 16 & 2 & SP & $\begin{array}{l}\text { Balaeş et al., 2013; Bernicchia, 2005; } \\
\text { Casieri et al., 2010; Ranadive et al., 2011; } \\
\text { Ryvarden and Gilbertson, } 1993\end{array}$ \\
\hline $\begin{array}{l}\text { Gloeophyllum } \\
\text { odoratum }\end{array}$ & 3 & 3 & 3 & 1 & 4 & 2 & SP & $\begin{array}{l}\text { Anastasi et al., 2010, Casieri et al., 2010; } \\
\text { Bernicchia, 2005; Erkkilâ and Niemelâ, } \\
\text { 1986; Ryvarden and Gilbertson, } 1993\end{array}$ \\
\hline $\begin{array}{l}\text { Grifola } \\
\text { frondosa* }\end{array}$ & 2 & 1 & 1 & 1 & 7 & 1 & SP & $\begin{array}{l}\text { Bernicchia, 2005; Hansent and Knudsen, } \\
\text { 1997; Orth et al., 1993; Ryvarden and } \\
\text { Gilbertson, 1993 }\end{array}$ \\
\hline $\begin{array}{l}\text { Gymnopilus } \\
\text { junonius }\end{array}$ & 2 & 2 & 2 & 4 & 14 & 1 & OS & $\begin{array}{l}\text { ARS; Balaeș et al., 2013; Rees and Strid, } \\
\text { 2001; Valentin et al., 2009 }\end{array}$ \\
\hline $\begin{array}{l}\text { Hemipholiota } \\
\text { populnea }\end{array}$ & 0 & 0 & 1 & 1 & 1 & 1 & OP & $\begin{array}{l}\text { ARS; Balaeș et al., 2013; Szczepkowski, } \\
2007\end{array}$ \\
\hline $\begin{array}{l}\text { Hymenopelis } \\
\text { radicata* }\end{array}$ & 1 & 1 & 2 & 1 & 4 & 2 & OS & ARS; Balaraju et al., 2010 \\
\hline $\begin{array}{l}\text { Hypholoma } \\
\text { fasciculare }\end{array}$ & 2 & 2 & 2 & 2 & 7 & 2 & OS & $\begin{array}{l}\text { Abrahao et al., 2008; Angelini et al., } \\
\text { 2012; Balaeș et al., 2013; Casieri et al., } \\
\text { 2010; Gramss et al., 1999 }\end{array}$ \\
\hline $\begin{array}{l}\text { Inonotus } \\
\text { hispidus }\end{array}$ & 3 & 3 & 1 & 3 & 23 & 2 & OP & $\begin{array}{l}\text { Aggelis et al., 2002; ARS; Balaeş et al., } \\
\text { 2013; Bernicchia, 2005; Casieri et al., } \\
\text { 2010; Gerault, 2006; Nerud and } \\
\text { Mišurcova 1996; Ryvarden and } \\
\text { Gilbertson, 1993 }\end{array}$ \\
\hline Irpex lacteus & 6 & 6 & 5 & 14 & 20 & 2 & OS & $\begin{array}{l}\text { Aggelis et al., 2002; Balaeş et al., 2013; } \\
\text { Bernicchia and Gorjón, 2010; Bernicchia, } \\
\text { 2005; Hattori, 2005; Levin et al., 2004; } \\
\text { Novotný et al., 2009; Ryvarden and } \\
\text { Gilbertson, } 1993\end{array}$ \\
\hline $\begin{array}{l}\text { Kuehneromyces } \\
\text { mutabilis }\end{array}$ & 1 & 1 & 1 & 1 & 3 & 2 & OS & $\begin{array}{l}\text { Balaess et al., 2013; Hansent and Knudsen, } \\
\text { 1992; Steffen et al., } 2007\end{array}$ \\
\hline $\begin{array}{l}\text { Laetiporus } \\
\text { sulphureus* }\end{array}$ & 1 & 1 & 2 & 3 & 23 & 2 & SP & $\begin{array}{l}\text { ARS; Bernicchia, 2005; Casieri et al., } \\
\text { 2010; Erkkilâ and Niemelâ, 1986; } \\
\text { Hansent and Knudsen, 1997; Hattori, } \\
\text { 2005; Ryvarden and Gilbertson, } 1993\end{array}$ \\
\hline
\end{tabular}




\begin{tabular}{|c|c|c|c|c|c|c|c|c|}
\hline $\begin{array}{l}\text { Lentinula } \\
\text { edodes }\end{array}$ & 3 & 3 & 4 & 3 & 12 & 2 & OS & $\begin{array}{l}\text { ARS; Bisen et al., 2010; Boer et al., 2004; } \\
\text { Kalmiş et al., 2008; Orth et al., } 1993\end{array}$ \\
\hline $\begin{array}{l}\text { Lentinus } \\
\text { neostrigosus* }\end{array}$ & 2 & 2 & 3 & 3 & 20 & 2 & OS & $\begin{array}{l}\text { ARS; Hansent and Knudsen, 1992; } \\
\text { Vaithanomsat et al., 2012 }\end{array}$ \\
\hline $\begin{array}{l}\text { Lentinus } \\
\text { tigrinus* }\end{array}$ & 3 & 3 & 4 & 3 & 12 & 2 & OS & $\begin{array}{l}\text { Aggelis et al., 2002; ARS; Hansent and } \\
\text { Knudsen, 1992; Moreira et al., } 2000\end{array}$ \\
\hline $\begin{array}{l}\text { Lenzites } \\
\text { betulina }\end{array}$ & 5 & 5 & 5 & 8 & 21 & 2 & OS & $\begin{array}{l}\text { Anastasi et al., 2010; Balaeş et al., 2013; } \\
\text { Balaes et al., 2014; Bernicchia, 2005; } \\
\text { Erkkilâ and Niemelâ, 1986; Guillén et al., } \\
\text { 2011; Hansent and Knudsen, 1997; } \\
\text { Hattori, 2005; Moturi et al., 2009; } \\
\text { Ryvarden and Gilbertson, } 1993\end{array}$ \\
\hline $\begin{array}{l}\text { Lycoperdon } \\
\text { pyriforme }\end{array}$ & 1 & 1 & 1 & 1 & 10 & 2 & OS & $\begin{array}{l}\text { Angelini et al., 2012; ARS; Balaess et al., } \\
\text { 2013; Casieri et al., 2010; Pegler et al., } \\
\text { 1995 }\end{array}$ \\
\hline $\begin{array}{l}\text { Megacollybia } \\
\text { platyphylla* }\end{array}$ & 1 & 1 & 1 & 1 & 2 & 2 & OS & ARS; Casieri et al., 2010 \\
\hline $\begin{array}{l}\text { Meripilus } \\
\text { giganteus* }\end{array}$ & 2 & 2 & 1 & 2 & 24 & 2 & SP & $\begin{array}{l}\text { ARS; Bernicchia, 2005; Kalmiş et al., } \\
\text { 2008; Ryvarden and Gilbertson, } 1994\end{array}$ \\
\hline $\begin{array}{l}\text { Merulius } \\
\text { tremellosus }\end{array}$ & 2 & 2 & 1 & 1 & 18 & 2 & OS & $\begin{array}{l}\text { ARS; Balaeş et al., 2013; Bernicchia and } \\
\text { Gorjón, 2010; Kum et al., 2011; } \\
\text { Szczepkowski, 2007 }\end{array}$ \\
\hline $\begin{array}{l}\text { Oudemansiella } \\
\text { mucida* }\end{array}$ & 2 & 1 & 1 & 2 & 5 & 2 & OS & ARS; Daniel et al., 1994; Gerault, 2005 \\
\hline $\begin{array}{l}\text { Panellus } \\
\text { stypticus* }\end{array}$ & 3 & 3 & 3 & 4 & 17 & 2 & OS & $\begin{array}{l}\text { Aggelis et al., 2002; ARS; Bernicchia and } \\
\text { Gorjón, 2010; Casieri et al., 2010; } \\
\text { Hansent and Knudsen, 1997; Nerud and } \\
\text { Mišurcova } 1996\end{array}$ \\
\hline $\begin{array}{l}\text { Peniophora } \\
\text { quercina* }\end{array}$ & 1 & 1 & 2 & 2 & 14 & 2 & OS & $\begin{array}{l}\text { ARS; Balaeş et al., 2013; Bernicchia, } \\
\text { 2005; Erkkilâ and Niemelâ, 1986; } \\
\text { Hansent and Knudsen, 1997Ryvarden and } \\
\text { Gilbertson, } 1994\end{array}$ \\
\hline $\begin{array}{l}\text { Phellinus } \\
\text { igniarius }\end{array}$ & 1 & 1 & 2 & 3 & 39 & 2 & SP & $\begin{array}{l}\text { ARS; Balaeş et al., 2013; Bernicchia, } \\
\text { 2005; Casieri et al., 2010; Erkkilâ and } \\
\text { Niemelâ, 1986; Hansent and Knudsen, } \\
\text { 1997; Ryvarden and Gilbertson, } 1994\end{array}$ \\
\hline $\begin{array}{l}\text { Phellinus } \\
\text { pomaceus }\end{array}$ & 1 & 1 & 2 & 1 & 24 & 2 & $\mathrm{OP}$ & $\begin{array}{l}\text { ARS; Balaeş et al., 2013; Bernicchia, } \\
\text { 2005; Casieri et al., 2010; Ranadive et al., } \\
\text { 2011; Ryvarden and Gilbertson, } 1994\end{array}$ \\
\hline $\begin{array}{l}\text { Phellinus } \\
\text { torulosus }\end{array}$ & 1 & 1 & 4 & 28 & 64 & 2 & $\mathrm{OP}$ & $\begin{array}{l}\text { Casieri et al., 2010; Nakasone and } \\
\text { Burdsall, 1995 }\end{array}$ \\
\hline $\begin{array}{l}\text { Phlebia } \\
\text { floridensis* }\end{array}$ & 3 & 3 & 4 & 2 & 6 & 2 & $\mathrm{O}$ & $\begin{array}{l}\text { Arora and Gill, 2005; ARS; Bernicchia } \\
\text { and Gorjón, 2010; Szczepkowski, } 2007\end{array}$ \\
\hline $\begin{array}{l}\text { Phlebia } \\
\text { radiata* }\end{array}$ & 6 & 7 & 5 & 2 & 15 & 2 & OS & $\begin{array}{l}\text { Anastasi et al., 2010; ARS; Casieri et al., } \\
\text { 2010; Hilden et al., 2005; Mäkelä et al., } \\
\text { 2006; Smith and Hesler, } 1968\end{array}$ \\
\hline $\begin{array}{l}\text { Pholiota } \\
\text { aurivella }\end{array}$ & 2 & 2 & 1 & 3 & 13 & 2 & $\mathrm{OP}$ & $\begin{array}{l}\text { Balaeş et al., 2013; Eichlerova et al., } \\
\text { 2006a }\end{array}$ \\
\hline $\begin{array}{l}\text { Piptoporus } \\
\text { betulinus* }\end{array}$ & 1 & 1 & 1 & 1 & 1 & 2 & SP & $\begin{array}{l}\text { Bernicchia, 2005; Casieri et al., 2010; } \\
\text { Erkkilâ and Niemelâ, 1986; Gerault, } \\
\text { 2006; Hansent and Knudsen, 1997; } \\
\text { Ryvarden and Gilbertson, } 1994\end{array}$ \\
\hline $\begin{array}{l}\text { Pleurotus } \\
\text { florida }\end{array}$ & 1 & 1 & 1 & 1 & 1 & 2 & OS & $\begin{array}{l}\text { ARS; Gbolagade et al., 2006; Pant and } \\
\text { Adholeya, } 2009\end{array}$ \\
\hline $\begin{array}{l}\text { Pleurotus } \\
\text { dryinus }\end{array}$ & 2 & 2 & 2 & 10 & 18 & 1 & OS & ARS; Eichlerova et al., 2006b; EOL \\
\hline Pleurotus & 7 & 7 & 2 & 11 & 43 & 2 & OS & Aggelis et al., 2002; Anastasi et al., 2010; \\
\hline
\end{tabular}




\begin{tabular}{|c|c|c|c|c|c|c|c|c|}
\hline ostreatus & & & & & & & & $\begin{array}{l}\text { Balaeș et al., 2013; Casieri et al., 2008; } \\
\text { Eichlerova et al., 2006a; Hansent and } \\
\text { Knudsen, 1997; Palmieri et al., 2005; } \\
\text { Pozdnyakova et al., } 2010\end{array}$ \\
\hline $\begin{array}{l}\text { Pleurotus } \\
\text { pulmonarius }\end{array}$ & 3 & 3 & 3 & 5 & 7 & 2 & OS & $\begin{array}{l}\text { ARS; Bernicchia, 2005; Eichlerova et al., } \\
\text { 2006c; Hattori, 2005; Orth et al., 1993; } \\
\text { Rigas et Dritsa, 2006; Ryvarden and } \\
\text { Gilbertson, } 1994\end{array}$ \\
\hline $\begin{array}{l}\text { Polyporus } \\
\text { alveolaris* }\end{array}$ & 2 & 2 & 5 & 9 & 20 & 1 & OS & $\begin{array}{l}\text { Barassa et al., 2009; Bernicchia, 2005; } \\
\text { Erkkilâ and Niemelâ, 1986; Lee et al., } \\
\text { 2010; Ryvarden and Gilbertson, } 1994\end{array}$ \\
\hline $\begin{array}{l}\text { Polyporus } \\
\text { brumalis }\end{array}$ & 3 & 3 & 2 & 22 & 27 & 2 & OS & $\begin{array}{l}\text { ARS; Bernicchia, 2005; Erkkilâ and } \\
\text { Niemelâ, 1986; Kum et al., 2011; Rigas si } \\
\text { Dritsa, 2006; Ryu et al., 2008; Ryvarden } \\
\text { and Gilbertson, } 1994\end{array}$ \\
\hline $\begin{array}{l}\text { Polyporus } \\
\text { squamosus }\end{array}$ & 2 & 2 & 1 & 25 & 28 & 2 & SP & $\begin{array}{l}\text { ARS; Casieri et al., 2010; Eichlerova et } \\
\text { al., 2006a }\end{array}$ \\
\hline Postia caesia & 1 & 1 & 1 & 7 & 30 & 2 & OS & $\begin{array}{l}\text { ARS; Balaeș et al., 2013; Eichlerova et } \\
\text { al., 2006a; Gerault, } 2006\end{array}$ \\
\hline Postia stiptica & 1 & 1 & 1 & 3 & 22 & 2 & OS & $\begin{array}{l}\text { ARS; Balaeș et al., 2013; Bernicchia, } \\
\text { 2005; Casieri et al., 2010; Hansent and } \\
\text { Knudsen, 1997; Ryvarden and Gilbertson, } \\
1994\end{array}$ \\
\hline $\begin{array}{l}\text { Pycnoporus } \\
\text { cinnabarinus }\end{array}$ & 2 & 2 & 4 & 12 & 28 & 2 & OS & $\begin{array}{l}\text { ARS; Bernicchia, 2005; Casieri et al., } \\
\text { 2010; Fedrova et al., 2013; Hansent and } \\
\text { Knudsen, 1997; Orth et al., 1993; } \\
\text { Ryvarden and Gilbertson, } 1994\end{array}$ \\
\hline $\begin{array}{l}\text { Trametes } \\
\text { gibbosa }\end{array}$ & 3 & 3 & 5 & 24 & 34 & 2 & OS & $\begin{array}{l}\text { ARS; Balaeș et al., 2013; Balaeș et al., } \\
\text { 2014; Bernicchia, 2005; Elisashvili and } \\
\text { Kachlishvili 2009; Elisashvili et al., 2009; } \\
\text { Fedrova et al., 2013; Hansent and } \\
\text { Knudsen, 1997; Orth et al., 1993; } \\
\text { Ryvarden and Gilbertson, 1994; } \\
\text { Szczepkowski, 2007 }\end{array}$ \\
\hline $\begin{array}{l}\text { Trametes } \\
\text { hirsuta }\end{array}$ & 5 & 5 & 5 & 38 & 52 & 2 & OS & $\begin{array}{l}\text { Aggelis et al., 2002; Balaeș et al., 2013; } \\
\text { Bernicchia, 2005; Casieri et al., 2010; } \\
\text { Erkkilâ and Niemelâ, 1986; Haibo et al., } \\
\text { 2009; Hansent and Knudsen, 1997; } \\
\text { Hattori, 2005; Orth et al., 1993; Ryvarden } \\
\text { and Gilbertson, 1994; Szczepkowski, } \\
\text { 2007; Tomšovsky and Homolka } 2003\end{array}$ \\
\hline $\begin{array}{l}\text { Trametes } \\
\text { ochracea }\end{array}$ & 3 & 3 & 5 & 19 & 23 & 2 & OS & $\begin{array}{l}\text { ARS; Balaeș et al., 2013; Bernicchia, } \\
\text { 2005; Casieri et al., 2010; Elisashvili and } \\
\text { Kachlishvili 2009; Gerault, 2006; } \\
\text { Ryvarden and Gilbertson, } \\
\text { Tomšovsky and Homolka } 2003\end{array}$ \\
\hline $\begin{array}{l}\text { Trametes } \\
\text { pubescens }\end{array}$ & 6 & 7 & 5 & 15 & 20 & 2 & OS & $\begin{array}{l}\text { Anastasi et al., 2010; ARS; Balaeș et al., } \\
\text { 2013; Bernicchia, 2005; Casieri et al., } \\
\text { 2008, 2010; Erkkilâ and Niemelâ, 1986; } \\
\text { Nikitina et al., 2005; Ryvarden and } \\
\text { Gilbertson, } 1994\end{array}$ \\
\hline $\begin{array}{l}\text { Trametes } \\
\text { suaveolens }\end{array}$ & 2 & 2 & 4 & 2 & 9 & 2 & SP & $\begin{array}{l}\text { ARS; Balaeș et al., 2013; Bernicchia, } \\
\text { 2005; Erkkilâ and Niemelâ, 1986; } \\
\text { Hansent and Knudsen, 1997; Knežević et } \\
\text { al., 2013; Ryvarden and Gilbertson, } 1994\end{array}$ \\
\hline $\begin{array}{l}\text { Trametes } \\
\text { trogii* }\end{array}$ & 6 & 6 & 5 & 2 & 9 & 2 & OS & $\begin{array}{l}\text { ARS; Bernicchia, 2005; Dhouib et al., } \\
\text { 2005; Levin et al., 2002, 2004; Ryvarden }\end{array}$ \\
\hline
\end{tabular}




\begin{tabular}{|l|l|l|l|l|l|l|l|l|}
\hline & & & & & & & & and Gilbertson, 1993 \\
\hline $\begin{array}{l}\text { Trametes } \\
\text { versicolor }\end{array}$ & 8 & 9 & 4 & 40 & 61 & 2 & OS & $\begin{array}{l}\text { Anastasi et al., 2010; Balaes et al., 2013; } \\
\text { Bernicchia, 2005; Casieri et al., 2010; } \\
\text { Erkkilâ and Niemelâ, 1986; Guillén et al., } \\
\text { 2011; Hattori, 2005; Levin et al., 2004; } \\
\text { Liu et al., 2004; Lorenzo et al., 2006; } \\
\text { Moturi et al., 2009; Orth et al., 1993; } \\
\text { Ryvarden and Gilbertson, 1994; } \\
\text { Tomšovsky and Homolka 2003; } \\
\text { Ungureanu et al., 2015 }\end{array}$ \\
\hline $\begin{array}{l}\text { Trichaptum } \\
\text { abietinum }\end{array}$ & 2 & 2 & 2 & 5 & 22 & 2 & OS & $\begin{array}{l}\text { ARS; Bernicchia, 2005; Eichlerova et al., } \\
\text { 2006a; Erkkilâ and Niemelâ, 1986; } \\
\text { Ryvarden and Gilbertson, 1994 }\end{array}$ \\
\hline $\begin{array}{l}\text { Trichaptum } \\
\text { biforme* }\end{array}$ & 2 & 2 & 2 & 7 & 18 & 2 & OS & $\begin{array}{l}\text { ARS; Bernicchia, 2005; Elisashvili et al., } \\
\text { 2009; Hansent and Knudsen, 1997 }\end{array}$ \\
\hline $\begin{array}{l}\text { Schizophyllum } \\
\text { commune }\end{array}$ & 4 & 3 & 2 & 6 & 42 & 2 & SP & $\begin{array}{l}\text { ARS; Balaes, et al., 2013; Bhatti et al., } \\
\text { 2008; Hansent and Knudsen, 1997; Levin } \\
\text { al., 2004; Li et al., 2009; } \\
\text { Szczepkowski, 2007 }\end{array}$ \\
\hline $\begin{array}{l}\text { Stereum } \\
\text { hirsutum }\end{array}$ & 1 & 1 & 1 & 2 & 11 & 2 & OS & $\begin{array}{l}\text { Balaeş et al., 2013; Guillén et al., 2011; } \\
\text { Orth et al., 1993; Szczepkowski, 2007 }\end{array}$ \\
\hline $\begin{array}{l}\text { Xylobolus } \\
\text { frustulatus }\end{array}$ & 1 & 1 & 1 & 1 & 3 & 1 & OS & $\begin{array}{l}\text { Balaeş et al., 2013; Cookson, 1995; } \\
\text { Hansent and Knudsen, 1997; Ranadive et } \\
\text { al., 2011 }\end{array}$ \\
\hline
\end{tabular}

*experimental results from the present research are included

\section{Analytical procedures}

For assessing the efficiency of dye degradation, the protocol described in Balaeș and collaborators (2013) has been used. Pure fungal cultures were grown on solid and liquid media and used as sources of inoculum. The presence / absence of laccase, and the enzyme activity has been highlighted through a modified protocol (Guo et al., 2011), using liquid medium supplemented with wheat bran (per $\mathrm{L}^{-1}: 6 \mathrm{~g}$ glucose, $3 \mathrm{~g}$ $\left(\mathrm{NH}_{4}\right)_{2} \mathrm{SO}_{4}, 6 \mathrm{~g}$ wheat bran, $\left.0.01 \mathrm{~g} \mathrm{CuSO}_{4}\right)$, and inoculated with pelletized mycelium $\left(10 \mathrm{~mL}\right.$ inoculum $\left.\mathrm{L}^{-1}\right)$. As a specific substrate, 2,2'-azino-bis(3-ethylbenzothiazoline-6sulphonic acid (ABTS) has been used. The reaction mixture contained $0.25 \mathrm{~mL} 50 \mathrm{mM}$ ABTS, $0.5 \mathrm{~mL} 0.1 \mathrm{M}$ acetate buffer, $0.25 \mathrm{~mL}$ enzyme extract. Substrate oxidation was monitored by measuring the increase of absorbance at $420 \mathrm{~nm}\left(\varepsilon 420,3.6 \cdot 104 \mathrm{M}^{-1} \mathrm{~cm}^{-1}\right)$, after $1 \mathrm{~min}$ at $25^{\circ} \mathrm{C}$. A unit of laccase activity was defined as the amount of enzyme oxidizing $1 \mu \mathrm{moL}$ of ABTS per minute in the considered analysis conditions (Bourbonnais et al., 1995).

\section{Data processing}

Compiled dataset included 6 variables (Table 1): number of ligninases, enzyme activity (expressed as classes from 1- poor enzyme activity / traces, to 7 - very strong activity), dye degradation efficiency (expressed as classes from 1 - very weak degradation, few dyes or no degradation at all, to 5 - very efficient degradation of different dyes), number of common host genera, number of total host genera and frequency (expressed as classes, 1 - less frequent, 2 - frequent or very frequent). A seventh variable refers to the type of nutrition - obligate saprotrophic (OS), sapro- 
parasitic (SP) and obligate parasitic species (OP). For particular tests, values from previous datasets were grouped into three categories corresponding to the nutrition type.

\section{Statistical interpretations}

For all statistical calculations and analysis XLStat (trial version) and MaxLite (freeware) softwares have been used. As data do not follow normal distribution, nonparametric tests were used. For assessing the correlations between different variables, Spearman correlation coefficients were used, at a confidence interval of 95\%. MannWhitney test has been used to compare variables related to the three types of fungi according to their nutrition. A Principal Component Analysis was run for a better view of correlations between all variables, considering the nutrition type as a qualitative supplementary variable.

\section{Results and Discussions}

The present investigation is an attempt to elucidate the role of ligninolytic enzyme system in ecological adaptation of lignicolous macrofungi in terms of diversity of substrata (hosts colonization). For this purpose, three hypotheses have been formulated.

\section{Hypothesis number 1: the species producing several types of ligninases are able to colonize many types of wood compared to the species that produce a smaller number of ligninases.}

One first step of our investigation was to analyze the correlation between the number of ligninolytic enzymes and the number of hosts. In the table of correlation (Table 2) it can be seen that there is a positive correlation $(\mathrm{r}=0.5529, p<0.0001)$ between the number of enzymes and the number of common host genera for all 69 species studied, while the correlation is weaker when considering the total host genera $(r=0.3738$, $p<0.0001)$. In the latter case there are also included species of trees / lignicolous substrate that are accidentally colonized by fungi and not as a normal behavior of a particular fungal species (e.g. Stereum hirsutum usually grows on deciduous trees, but it has been reported also on coniferous wood, although one may not expect to find $S$. hirsutum on this substrate in the field). Hence, using the number of common hosts for assessing the correlation between the number of ligninolytic enzymes and host diversity gives a better understanding of how the ligninolytic enzymes system is influencing the ecology of these fungi.

Table 2. Correlations between ligninolytic enzyme system and number of hosts - Spearman correlation coefficients ( $r$ values in upper, and $p$ values, two-tailed, in lower matrix; confidence interval 95\%; with bold are marked the relevant results)

\begin{tabular}{|l|c|c|c|c|c|}
\hline & $\begin{array}{c}\text { Number of } \\
\text { enzymes }\end{array}$ & $\begin{array}{c}\text { Enzyme } \\
\text { activity }\end{array}$ & $\begin{array}{c}\text { Dye degradation } \\
\text { efficiency }\end{array}$ & $\begin{array}{c}\text { Common } \\
\text { host genera }\end{array}$ & $\begin{array}{c}\text { Total host } \\
\text { genera }\end{array}$ \\
\hline Number of enzymes & & 0.9898 & 0.5712 & $\mathbf{0 . 5 5 2 9}$ & 0.3738 \\
\hline Enzyme activity & $<0.0001$ & & 0.5902 & $\mathbf{0 . 5 6 0 4}$ & 0.3883 \\
\hline $\begin{array}{l}\text { Dye degradation } \\
\text { efficiency }\end{array}$ & $<0.0001$ & $<0.0001$ & & $\mathbf{0 . 4 5 5 9}$ & 0.182 \\
\hline Common host genera & $<\mathbf{0 . 0 0 0 1}$ & $<\mathbf{0 . 0 0 0 1}$ & $<\mathbf{0 . 0 0 0 1}$ & & 0.759 \\
\hline Total host genera & 0.0016 & 0.001 & 0.1344 & $<0.0001$ & \\
\hline
\end{tabular}


We have included in our tests one other variable: the general enzyme activity, expressed as classes of efficiency (data collected from literature and completed with our own results). These data have the disadvantage of being organized as classes: the quantitative interpretation is thus affected by subjectivity to some degree. Raw quantitative data could not be used due to very different experimental conditions of various researchers. Including of this variable had the role of verifying if there is still a positive correlation between enzymes and hosts number. The correlation in this case was slightly stronger $(\mathrm{r}=0.5604, p<0.0001)$, re-confirming $\mathrm{h} 1$.

A second attempt to verify this hypothesis consisted in using a new variable, derived from the first one - the efficiency of dye degradation as a measure of enzyme versatility. Ligninolytic enzymes are very versatile and attack a large spectrum of chemical compounds with structure similar to lignin. This property confers the ability to degrade different human made aromatic compounds, hydrocarbons, dyes with heterocycles (Balaeș et al., 2014), while in natural conditions these fungi degrade lignin and also other chemical compounds from wood (Deacon, 2006). Considering these facts, we hypothesize that the versatility of ligninolytic enzymes could also be a factor that influence the ecological adaptation in terms of colonizing very different types of wood (varied chemical composition). However, we found weaker correlation compared to previous variables $(\mathrm{r}=0.4559, p<0.0001)$.

The Principal Component Analysis (PCA) is an explanatory statistical tool used for visualization of data and to a lesser extent for testing hypotheses. Running PCA lead to confirm the results from previous tests, offering, in the same time, a largely view over the connections between variable. The procedure is based on the projection of all variables (six + one in our case) onto two axes, considering the first two factors that are contributing to the variability. We have considered the first six variable as principal quantitative variables and the seventh one (Nutrition type) as a supplementary qualitative variable.

In Fig. 1 we can observe on the correlation circle that the first two components explain $73 \%$ of the data variability, making the projection a trusting one. A very strong positive correlation is found between the Number of enzymes and Enzyme activity, as it would have been expected. A good positive correlation is seen between these two variables and Common host genera on a side and Dye degradation efficiency on the other side. The position of projection points at a particular distance from the circle prove that the projection should be considered with caution for these two variables.

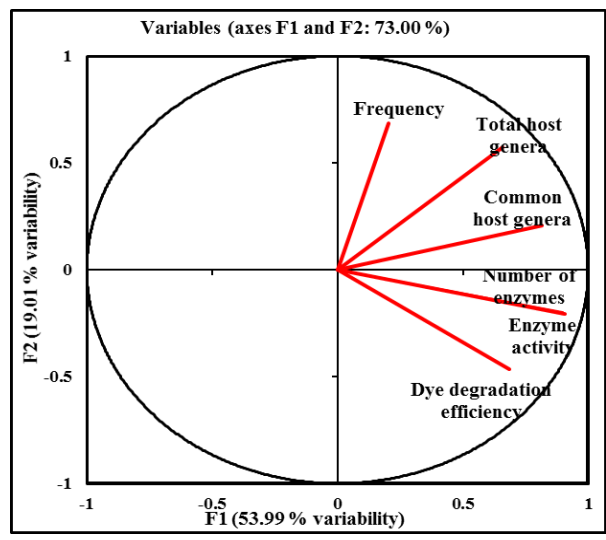

Figure 1. Circle of correlation between factors and variables after Principal Component Analysis (numbers on axes represent the correlation coefficients) 
As seen in Table 3, factor loadings for these variables have the highest values on F1 dimension and second values (close to the first ones) on F3 and F4 dimensions respectively. The Total host genera variable is better projected on the chart (Table 3) and it can be observed that it is not correlated with Number of enzymes. The highest values of factor loadings for Frequency are on the F2 and F3 dimensions and are almost equal, and therefore no explanations can be assumed based on the projection.

Table 3. Factor loadings for the six quantitative variables in Principal Component Analysis (with bold are marked the highest values for each variable)

\begin{tabular}{|l|r|r|r|r|r|r|}
\hline \multicolumn{1}{|c|}{ VariablesLFactors } & \multicolumn{1}{c|}{ F1 } & \multicolumn{1}{c|}{ F2 } & \multicolumn{1}{c|}{ F3 } & \multicolumn{1}{c|}{ F4 } & \multicolumn{1}{c|}{ F5 } & \multicolumn{1}{c|}{ F6 } \\
\hline Number of enzymes & $\mathbf{0 . 9 0 0}$ & -0.199 & 0.263 & -0.273 & -0.015 & -0.085 \\
\hline Common host genera & $\mathbf{0 . 8 1 5}$ & 0.206 & $\mathbf{- 0 . 4 4 3}$ & 0.067 & 0.303 & 0.000 \\
\hline Frequency & 0.205 & $\mathbf{0 . 6 8 7}$ & $\mathbf{0 . 6 6 4}$ & 0.205 & 0.060 & 0.000 \\
\hline Enzyme activity & $\mathbf{0 . 9 0 7}$ & -0.209 & 0.253 & -0.250 & -0.022 & 0.087 \\
\hline Total host genera & $\mathbf{0 . 6 5 7}$ & $\mathbf{0 . 5 7 4}$ & -0.415 & -0.007 & -0.259 & -0.001 \\
\hline $\begin{array}{l}\text { Dye degradation } \\
\text { efficiency }\end{array}$ & $\mathbf{0 . 6 8 5}$ & -0.463 & 0.046 & $\mathbf{0 . 5 5 4}$ & -0.080 & -0.003 \\
\hline
\end{tabular}

\section{Hypothesis number 2 - OS species have a greater potential in degrading wood (by degrading lignin) than SP and OP species.}

OS macrofungi use products derived from wood decomposition as sources of nutrients: cellulose and hemicelluloses are primary sources of $\mathrm{C}$ and energy, while lignin is degraded especially for making cellulose and other constituents of wood more accessible (Deacon, 2006). Since OS are dependent on the dead wood constituents, it was assumed that these species tend to have a highly versatile and active enzymes system compared to SP and OP macrofungi, which are using additional or mainly other strategies for nutrition. In other words, the second hypothesis assumed that OS have more active enzyme and degrade a broader spectrum of synthetic dyes (different chemical structure), being more versatile.

When applying the Mann-Whitney test for two by two datasets (Table 4) we observed that there is a significant superiority of dye degradation efficiency of OS compared to SP (one tailed $p$ value 0.047 ) and to OP (one tailed $p$ value 0.048 ), while between SP and OP there are no significant differences for this property. Concerning enzyme activity, OS produce more highly active enzymes than SP (one tailed $p$ 0.008) and OP (one tailed $p$ 0.046). These results are confirming our hypothesis.

Table 4. Mann-Whitney test (right-tailed test) for comparing the enzyme activity and dye degradation efficiency for the three type of macrofungi (the Mann-Whitney's $U$ is normalized and tested against the normal distribution)

\begin{tabular}{|l|r|r|r|r|r|r|}
\hline & \multicolumn{2}{|c|}{ Dye degradation efficiency } & \multicolumn{3}{c|}{ Enzyme activity } \\
\cline { 2 - 7 } & \multicolumn{1}{|c|}{ OS-SP } & \multicolumn{1}{c|}{ OS-OP } & \multicolumn{1}{c|}{ SP-OP } & OS-SP & \multicolumn{1}{c|}{ OS-OP } & \multicolumn{1}{c|}{ SP-OP } \\
\hline $\mathrm{U}$ & 469.000 & 222.500 & 64.000 & 514.000 & 223.500 & 57.000 \\
\hline $\mathrm{U}$ (expected value) & 368.000 & 161.000 & 56.000 & 368.000 & 161.000 & 56.000 \\
\hline U (variance) & 3651.782 & 1369.084 & 200.316 & 3627.943 & 1381.644 & 193.233 \\
\hline Z (observed value) & 1.671 & 1.662 & 0.565 & 2.424 & 1.681 & 0.072 \\
\hline Z (critical value) & 1.645 & 1.645 & 1.645 & 1.645 & 1.645 & 1.645 \\
\hline One-tailed p-value & 0.047 & 0.048 & 0.286 & 0.008 & 0.046 & 0.471 \\
\hline Alpha & 0.05 & 0.05 & 0.05 & 0.05 & 0.05 & 0.05 \\
\hline
\end{tabular}


Lignin is considered a barrier for wood decomposition, but woody species also produce tannins, alkaloids, resins and other types of chemical compounds with defensive and/or structural role. Lignin is formed from three different monomers: $p$ coumaryl alcohol, coniferyl alcohol and sinapyl alcohol, and their varied ratio give spatial different structures for each species. Broad leaves trees (dicotiledons) have lignine made predominantly from $p$-coumaryl, while coniferous trees contain lignin composed mainly from coniferyl alcohol. Ligninases are versatile enzymes, able to breakdown the lignin with its different structure from a species to another, as well as oxidize other compounds polyphenols and heterocyclic compounds (Elisashvili et al., 2010). For OS macrofungi ligninases play important roles in their nutrition.

The Principal Component Analysis also offered information for a better view of ecological features of the three groups of macrofungi separated based on their nutrition type. Fig. 2 shows the projection of each observation (species characteristics) on the chart, grouped according to the nutrition type (three colors for OS, SP and OP). There is a distinct projection of the three groups, with only OS sharing some features with other two groups and with a higher dispersal on the chart, meaning there is a higher variability inside group, in terms of ligninases synthesis and host spectrum. OP group is more homogenous, but three species have particular characteristics, with Armillaria mellea (AM) and Phellinus torulosus (PT) having a very large host spectrum and producing ligninases to some degree, while Hemipholiota populnea (HP) has a completely distinct projection with a reduced host range (only Populus) and does not produce known ligninases.

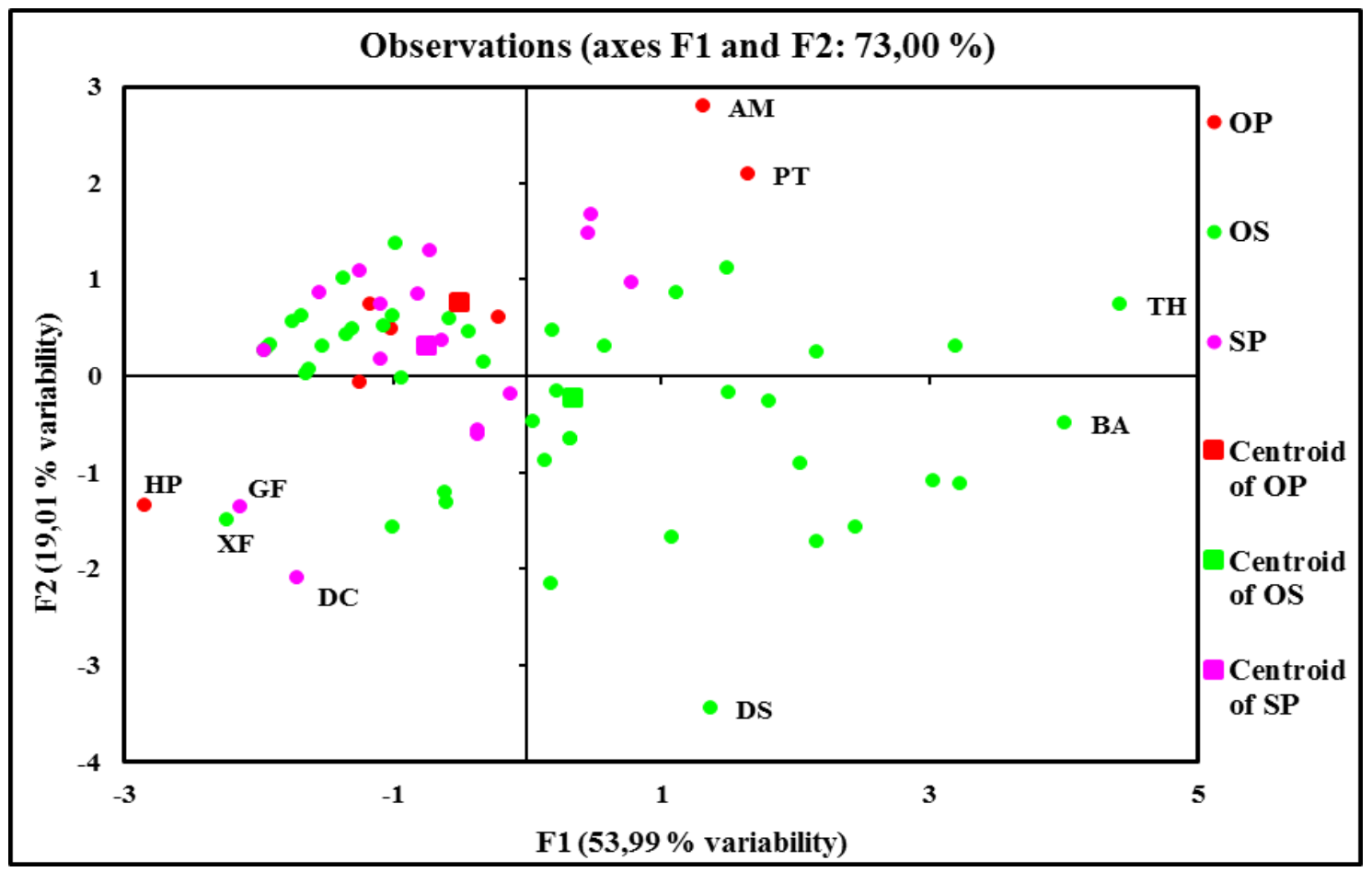

Figure 2. The projections of observations (species characteristics) on the first two factors axes (AM - A. mellea, BA - B. adusta, DC - D. caperata, DS - D. squalens, GF - G. frondosa, HPH. populnea, $P T-P$. torulosus, $T H-$ Trametes hirsute, $X F-X y l o b o l u s$ frustulatus; legend: $O P$ - obligate parasitic, $O S$ - obligate saprotrophic, $S P$ - sapro-parasitic macrofungi) 
Among the SP species, Grifola frondosa (GF) and Datronia caperata (DC) possess features distinct from the other species in the group, with reduced host range, less frequent and producing only laccase in small amounts. Four OS species have characteristics different from other species in the group: Bjerkandera adusta (BA) and Trametes hirsuta $(\mathrm{TH})$ produce many enzymes with strong activity and have a large host spectrum, while Xylobolus frustulatus (XF) produces few enzymes and has a reduced host spectrum (only Quercus) and Dichomitus squalens (DS) with strong enzyme activity but reduced host spectrum.

The projection of the species based on the nutrition type offers an interesting view of their ecological behaviors. The higher variability for OS fungi can be explained through their very different strategies for survival and development, some species growing on wood not affected by decay, while other grow on rotten wood; some species manifest antagonism against competitors, while other expand their mycelium in soil and litter, being more opportunistic. In contrast, SP and OP appear to be more specialized on their ecological niche, probably their strategies being oriented toward "fighting" their hosts.

\section{Hypothesis number 3 - competitive species (frequent species) produce highly active enzymes.}

To test this assumption, we verified if there is a positive correlation between frequency and enzyme activity / dye degradation efficiency. As it can be observed in Table 5, there is no correlation, at least in the case of our limited data, and we might assume that other factors are being involved in the process (hosts number, host frequency, other ecological factors). The third hypothesis has been rejected.

Table 5. Correlations between frequencies and enzyme activity / dye degradation efficiencySpearman correlation coefficients ( $r$ values in upper, and $p$ values, two-tailed, in lower matrix; confidence interval 95\%)

\begin{tabular}{|l|c|c|c|}
\hline & Enzyme activity & Dye degradation efficiency & Frequency \\
\hline Enzyme activity & & 0.5902 & 0.1650 \\
\hline Dye degradation efficiency & $<0.0001$ & & -0.0383 \\
\hline Frequency & 0.1755 & 0.7544 & \\
\hline
\end{tabular}

An attempt to include data for distribution of fungal species has been abandoned since the distribution is strongly dependent on their hosts and production of ligninases is irrelevant in this case. The limitations of our study consist in the reduced availability of data concerning ligninase production and activity for many species of macrofungi, forcing us to take into consideration only 69 species. Different macrofungi might produce a particular ligninase in different amounts or with a different activity, and a reasonable assumption is that the quantity and quality of ligninases also play roles in wood degradation efficiency. In these circumstances is difficult to compare the ligninolytic activity of certain species as different authors are using varied protocols and particular conditions to test the enzyme activity. However, using classes of efficiency, we overcome this limitation and tested the formulated hypotheses.

In summary, we have investigated the influence of ligninolytic enzyme system over ecological success of lignicolous fungi in terms of hosts' spectrum. We assumed that fungal species producing several types of ligninases are cosmopolitan and colonize a broader spectrum of tree hosts and we found positive correlation that sustain this 
hypothesis $(\mathrm{r}=0.5529, \mathrm{p}<0.0001)$. Our analysis suggests that obligate saprotrophic fungi tend to degrade several types of wood and more efficiently due to higher enzyme activity and versatility. It appears that this group of macrofungi is more heterogeneous in terms of ligninases production and host range, probably due to other ecological factors involved in their adaptation strategies than in the case of parasitic species.

In was assumed that fungal species with a larger host spectrum produce highly active and versatile ligninases, but this hypothesis has been rejected.

Future studies might contribute further to the understanding of the ecological importance of ligninases.

Aknoledgements. This study was funded by Alexandru Ioan Cuza University of Iasi, Romania, through the project 13/3.12.2015, code GI-2015-10, Grant Competition for young researchers of UAIC.

\section{REFERENCES}

[1] Abrahao M.C., Gugliotta A.M., Silva R.D., Fujieda R.J.Y., Boscolo M., Gomes E. (2008): Ligninolytic activity from newly isolated basidiomycete strains and effect of these enzymes on the azo dye orange II decolourisation. - Annals of Microbiology 58: 427-432.

[2] Aggelis G., Ehaliotis C., Nerud F., Stoychev I., Lyberatos G., Zervakis G.I. (2002): Evaluation of white-rot fungi for detoxification and decolorization of effluents from the green olive debittering process. - Applied Microbiology and Biotechnology 59: 353-360.

[3] Anastasi A., Prigione V., Varese G.C. (2010): Industrial dye degradation and detoxification by basidiomycetes belonging to different eco-physiological groups. Journal of Hazardous Materials 177: 260-267.

[4] Angelini P., Bistocchi G., Arcangeli A., Venanzoni R. (2012): Preliminary checklist of the macromycetes from Collestrada forest ecosystems in Perugia (Italy). - Mycotaxon 120: 505.

[5] Arora D.S., Gill P.K. (2005): Production of ligninolytic enzymes by Phlebia floridensis. World Journal of Microbiology \& Biotechnology 21: 1021-1028.

[6] ARS (Agricultural Research Service, United State Department of Agriculture, http://nt.ars-grin.gov/fungaldatabases/fungushost/FungusHost.cfm).

[7] Asgher M., Noreen S., Bhatti H.N. (2010): Decolorization of dye containing textile industry effluents using Ganoderma lucidum IBL-05 in still culture. - Water Environment Research 82(4): 357-361.

[8] Balaeș T., Mangalagiu I.I., Tănase C. (2013): Lignicolous macromycetes: potential candidates for bioremediation of synthetic dyes. - Revista de Chimie 64(9): 790-795.

[9] Balaeş T., Tănase C., Butnariu C.D. (2014): The use of heavy metals in mycoremediation of synthetic dyes. - Central European Journal of Biology 9(7): 659-667.

[10] Balaeş T., Tănase C. (2013): Optimization of nutritional conditions for the mycoremediation of synthetic dyes. - Romanian Biotechnological Letters 18(6): 88048811.

[11] Balaraju K., Park K., Jahagirdar S., Kaviyarasan V. (2010): Production of cellulase and laccase enzymes by Oudemansiella radicata using agro wastes under solid-state and submerged conditions. - Research in Biotechnology 1: 21-28.

[12] Baldrian P. (2004): Purification and characterization of laccase from the white-rot fungus Daedalea quercina and decolorization of synthetic dyes by the enzyme. - Applied Microbiology and Biotechnology 63: 560-563.

[13] Baldrian P. (2006): Fungal laccases occurrence and properties. - FEMS Microbiology Reviews 30: 215-242. 
[14] Barrasa J.M., Martínez A.T., Martínez M.J. (2009): Isolation and selection of novel basidiomycetes for decolorization of recalcitrant dyes. - Folia Microbiologica 54(1): 5966.

[15] Bernicchia A. (2005): Fungi Europaei, Vol. X: Polyporaceae s.l. - Edizioni Candusso, Bologna.

[16] Bernicchia A., Gorjón S.P. (2010): Corticiaceae s.l. Fungi Europaei, nº12. - Edizioni Candusso, Bologna.

[17] Bhatti H.N., Akram N., Asgher M. (2008): Optimization of culture conditions for enhanced decolorization of Cibacrom Red FN-2BL by Schyzophyllum commune IBL-6. Applied Biochemistry and Biotechnology 149: 255-264.

[18] Bisen P.S., Baghel R.K., Sanodiya B.S.,Thakur G.S., Prasad G.B.K.S. (2010): Lentinus edodes: A macrofungus with pharmaceutical activities. - Current Medicinal Chemistry 17: 2419-2430.

[19] Boer C.G., Obici L., Marques De Souza C.G., Peralta R.M. (2004): Decolorization of synthetic dyes by solid state cultures of Lentinula (Lentinus) edodes producing manganese peroxidase as the main ligninolytic enzyme. - Bioresource Technology 94: 107-112.

[20] Bourbonnais R., Paice M.G., Reid I.D., Lanthier P., Yaguchi M. (1995): Lignin oxidation by laccase isozymes from Trametes versicolor and role of the mediator 2,2-azinobis (3ethylbenzthiazoline-6-sulphonate) in kraft lignin depolymerisation. - Applied Environmental Microbiology 61: 1876-1880.

[21] Casieri L., Anastasi A., Prigione V., Varese G. C. (2010): Survey of ectomycorrhizal, litter-degrading, and wood-degrading Basidiomycetes for dye decolorization and ligninolytic enzyme activity. -Antonie van Leeuwenhoek 98: 483-504.

[22] Casieri L., Varese G.C., Anastasi A., Prigione V., Svobodova K., Marchisio V.F., Novoný Č. (2008): Decolorization and detoxication of reactive industrial dyes by innnobilized fungi Trametes pubescens and Pleurotus ostreatus. - Folia Microbiologica 53(1): 44-52.

[23] Cookson L.J. (1995): Reliability of poly B-411, a polymeric anthraquinone-based dye, in determining the rot type caused by wood-inhabiting fungi. - Applied Environmental Microbiology 61(2): 801-803.

[24] D'Souza-Ticlo D., Sharma D., Raghukumar C. (2009): A thermostable metal-tolerant laccase with bioremediation potential from a marine-derived fungus. - Marine Biotechnology 11: 725-737.

[25] Daniel G., Volc I.J., Kubatova E. (1994): Pyranose oxidase, a major source of H202 during wood degradation by Phanerochaete chrysosporium, Trametes versicolor, and Oudemansiella mucida. - Applied and Environmental Microbiology 60(7): 2524- 2532.

[26] Deacon J. W. (2006): Fungal Biology, 4-th edition. - Blackwell Publishing, Cornwell.

[27] Dhouib A., Hamza M., Zouari H., Mechichi T., Hmidi R., Labat M., Martinez M.J., Sayadi S. (2005): Screening for ligninolytic enzyme production by diverse fungi from Tunisia. - World Journal of Microbiology \& Biotechnology 21: 1415-1423.

[28] Diamandis S., Perlerou C. (2001): The mycoflora of the chestnut ecosystem in Greece. Forest Snow and Landscape Research 76(3): 499- 504.

[29] Eichlerová I., Homolka L., Lisá L., Nerud F. (2006a): The influence of extracellular $\mathrm{H}_{2} \mathrm{O}_{2}$ production on decolorization ability in fungi. - Journal of Basic Microbiology 46(6): 449-455.

[30] Eichlerová I., Homolka L., Nerud F. (2006b): Ability of industrial dyes decolorization and ligninolytic enzymes production by different Pleurotus species with special attention on Pleurotus calyptratus, strain CCBAS 461. - Process Biochemistry 41: 941-946.

[31] Eichlerová I., Homolka L., Nerud F. (2006c): Synthetic dye decolorization capacity of white rot fungus Dichomitus squalens. - Bioresource Technology 97: 2153-2159. 
[32] Elisashvili V., Kachlishvili E. (2009): Physiological regulation of laccase and manganese peroxidase production by white-rot basidiomycetes. - Journal of Biotechnology 144: 3742.

[33] Elisashvili V., Kachlishvili E., Khardziani T., Agathos S.N. (2010): Effect of aromatic compounds on the production of laccase and manganese peroxidase by white-rot basidiomycetes. - Journal of Industrial Microbiology and Biotechnology 37: 1091-1096.

[34] Elisashvili V., Kachlishvili E., Tsiklauri N., Metreveli E., Khardziani T., Agathos S.N. (2009): Lignocellulose-degrading enzyme production by white-rot Basidiomycetes isolated from the forests of Georgia. - World Journal of Microbiology and Biotechnology 25: 331-339.

[35] EOL (Enciclopedia of Life): http://eol.org/

[36] Erkkilä R., Niemelä T. (1986): Polypores in the parks and forests of the city of Helsinki. - Karstenia 26: 1-40.

[37] Fedorova T.V., Shakhova N.V., Klein O. I., Glazunova O. A., Maloshenok L. G., Kulikova N. A., Psurtseva N. V., Koroleva O. V. (2013): Comparative analysis of the ligninolytic potential of basidiomycetes belonging to different taxonomic and ecological groups. - Applied Biochemistry and Microbiology 49(6): 570-580.

[38] Gbolagade J., Ajayi A., Oku I., Wankasi D. (2006): Nutritive value of common edible mushrooms from South Nigeria. - Global Journal of Biotechnology \& Biotechnology 1(1): 16-21.

[39] Gerault A. (2005): Florule evolutive des Basidiomycotina du Finistere. Heterobasidiomycetes. Tricholomatales. Version 2.1.

[40] Gerault A. (2006): Florule evolutive des Basidiomycotina du Finistere. Homobasidioycetes. Hymenochaetales, Lachnocladiales, Ganodermatales, Poriales, Polyporales, Schizophyllales, Version 1.0.

[41] Gilbert G.S., Sousa W.P. (2002): Host specialization among wood-decay polypore fungi in a Caribbian mangrove forest. - Biotropica 34(3): 396-404.

[42] Gramss G., Voigt K.-D., Kirsche B. (1999): Degradation of polycyclic aromatic hydrocarbons with three to seven aromatic rings by higher fungi in sterile and unsterile soils. - Biodegradation 10: 51-62.

[43] Grąz M., Jarosz-WilkołazkA A. (2011): Oxalic acid, versatile peroxidase secretion and chelating ability of Bjerkandera fumosa in rich and limited culture conditions. - World Journal of Microbiology and Biotechnology 27: 1885-1891.

[44] Guillén Y., Palfner G., Machuca A. (2011): Screening for lignocellulolytic enzymes and metal tolerance in isolates of wood-rotting fungi from Chile. - Intersciencia 36(11): 860 868.

[45] Guo L.Q., Lin S.X., Zheng X.B., Huang Z.R., Lin J.F. (2011): Production, purification and characterization of a hermostable laccase from a tropical white-rot fungus. - World Journal of Microbiology and Biotechnology 27: 731-735.

[46] Haibo Z., Yinglong Z., Feng H., Peiji G., Jiachuan C. (2009): Purification and characterization of a thermostable laccase with unique oxidative characteristics from Trametes hirsuta. - Biotechnology Letters 31: 837-843.

[47] Hansent L., Knudsen H. (1992, 1997): Nordic Macromycetes, Vol II: Polyporales, Boletales, Agaricales, Russulales. Nordsvamp, Copenhagen, 474 p; Vol. III: Heterobasidioid Aphyllophoroid and Gastromycetoid Basidiomycetes. - Nordsvamp, Copenhagen, $444 \mathrm{p}$.

[48] Hattori, T. (2005): Diversity of wood-inhabiting polypores in temperate forest with different vegetation types in Japan. - Fungal Diversity 18: 73-88.

[49] Hildén K., Martinez A.T., Hatakka A., Lundell T. (2005): The two manganese peroxidases $\mathrm{Pr}-\mathrm{MnP} 2$ and $\mathrm{Pr}-\mathrm{MnP} 3$ of Phlebia radiata, a lignin-degrading basidiomycete, are phylogenetically and structurally divergent. - Fungal Genetics and Biology 42: 403419. 
[50] Kalmiş E., Yaşa I., Kalyoncu F., Pazarbaşi B., Koçyiğit, A. (2008): Ligninolytic enzyme activities in mycelium of some wild and commercial mushrooms. - African Journal of Biotechnology 7 (23): 4314-4320.

[51] Knežević A., Milovanović I., Stajić M., Vukojević J. (2013): Trametes suaveolens as ligninolytic enzyme producer. - Matica Srpska Journal of Natural Sciences 124: 437-444.

[52] Kum H., LEE S., Ryu S., Choi H.T. (2011): Degradation of endocrine disrupting chemicals by genetic transformants with two lignin degrading enzymes in Phlebia tremellosa. - The Journal of Microbiology 49 (5): 824-827.

[53] Lee J.S., Woo E.J., Oh K.H., Kim J.-J., Lim Y.W. (2010): The first report of two species of Polyporus (Polyporaceae, Basidiomycota) from South Korea. - The Journal of Microbiology 48(6): 748-753.

[54] Levin L., Papinutti L., Forchiassin F. (2004): Evaluation of Argentinian white rot fungi for their ability to produce lignin-modifying enzymes and decolorize industrial dyes. Bioresource Technology 94: 169-176.

[55] Levin L., Ramos A., Forchiassin F. (2002): Copper induction of lignin-modifying enzymes in the white-rot fungus Trametes trogii. - Mycologia 94(3): 377-383.

[56] Li X., Jia R., Li P., ANG S. (2009): Response surface analysis for enzymatic decolorization of Congo red by manganese peroxidase. - Journal of Molecular Catalysis B: Enzymatic 56: 1-6.

[57] Liers C., Bobeth C., Pecyna M., Ullrich R., Hofrichter M. (2010): DyP-like peroxidases of the jelly fungus Auricularia auricula-judae oxidize nonphenolic lignin model compounds and high-redox potential dyes. - Applied Microbiology and Biotechnology 85: $1869-1879$.

[58] Liu W., Chao Y., Yang X., Bao H., Qian S. (2004): Biodecolorization of azo, anthraquinonic and triphenylmethane dyes by white-rot fungi and a laccase-secreting engineered strain. - Journal of Industrial Microbiology and Biotechnology 31: 127-132.

[59] Lorenzo M., Moldes D., Sanromán M.A. (2006): Effect of heavy metals on the production of several laccase isoenzymes by Trametes versicolor and on their ability to decolourise dyes. -Chemosphere 63: 912-917.

[60] Mäkelä M.R., Hildén K.S., Hakala T.K., Hatakka A., Lundell T.K. (2006): Expression and molecular properties of a new laccase of the white rot fungus Phlebia radiata grown on wood. - Current Genetics 50: 323-333.

[61] Matsushita N., Suzuki K. (2005): Identification of Armillaria species in Japan using PCRRFLP analysis of rDNA intergenic spacer region and comparison of Armillaria species in the world. - Journal for Forest Research 10: 173-179.

[62] Minter D.W., Rodríguez Hernández M., Mena Portales J. (2001): Fungi of the Caribbean: an annotated checklist. - PDMS Publishing, Isleworth.

[63] Moreira M.T., Mielgo I., Feijoo G., Lema J.M. (2000): Evaluation of different fungal strains in the decolourisation of synthetic dyes. - Biotechnology Letters 22: 1499-1503.

[64] Moturi B., Singara Charya M.A. (2009): Decolourisation of crystal violet and malachite green by fungi. - Science World Journal 4(4): 28-33.

[65] Nagy L.G., Riley R., Tritt A., Adam C., Daum C., Floudas D., Sun H., Yadav J.S., Pangilinan J., Larsson H.K., Matsuura K., Barry K., LaButti K., Kuo R., Ohm R.A., Bhattacharya S.S., Shirouzu T., Yoshinaga Y., Martin F.M., Grigoriev I.V., Hibbett D.S. (2015): Comparative genomics of early-diverging mushroom-forming fungi provides insights into the origins of lignocellulose decay capabilities. - Molecular Biology and Evolution doi:10.1093/molbev/msv337.

[66] Nakasone K.K., Burdsall JR. H.H. (1995): Phlebia species from eastern and southeastern United States. - Mycotaxon 54: 335-359.

[67] Negrean G., Anastasiu P. (2004): Hirneola auricula-judae in Romania. - Contribuţii Botanice, Grădina Botanică "Alexandru Borza" Cluj-Napoca 39: 21-39. (in Romanian)

[68] Nerud F., Mišurcova Z. (1996): Distribution of ligninolytic enzymes in selected white-rot fungi. - Folia Mierobiologica 41(3): 264-256. 
[69] Nikitina O.V., Shleev S.V., Gorshina E.S., Rusinova T.V., Serezhenkov V.A., Burbaev D.S., Belovolova L.V., Yaropolov A.I. (2005): Isolation and purification of enzymes from ligninolytic complex of the basidial fungus Trametes pubescens (Schumach.) Pilát and study of their properties. - Biochemistry (Moscow) 70(11): 1274-1279.

[70] Novotný Č., Cajthaml T., Svobodová K., Šušla M., Šašek V. (2009): Irpex lacteus, a white-rot fungus with biotechnological potential. - Folia Microbiologica 54(5): 375-390.

[71] Novotný Č., Trošt N., Šušla M., Svobodova K., Mikeskova H., Valkova H., Malachova K., Pavko A. (2012): The use of the fungus Dichomitus squalens for degradation in rotating biological contactor conditions. - Bioresource Technology 114: 241-246.

[72] Orth A.B., Royse D.J., Tien M. (1993): Ubiquity of lignin-degrading peroxidases among various wood-degrading fungi. - Applied and Environmental Microbiology 59(12): 4017-4023.

[73] Otieno W., Pérez sierra A., Termorshuizen A. (2003): Characterization of Armillaria isolates from tea (Cammelia sinensis) in Kenya. - Mycologia 95(1): 160-175.

[74] Palmieri G., Cennamo G., Sannia G. (2005): Remazol Brilliant Blue R decolourisation by the fungus Pleurotus ostreatus and its oxidative enzymatic system. - Enzyme and Microbial Technology 36: 17-24.

[75] Pant D., Adholeya A. (2009): Concentration of fungal ligninolytic enzymes by ultrafiltration and their use in distillery effluent decolorization. - World Journal of Microbiology and Biotechnology 25: 1793-1800.

[76] Pegler D.N., Læssøe T., Spooner B.M. (1995): British puffballs, earthstars and stinkhorns. An account of the British Gasteroid Fungi. - Royal Botanic Gardens, Kew.

[77] Petersen R.H., Hughes K.W., Redhead S.A., Psurtseva N., Methven A.S. (1999): Mating systems in the Xerulaceae (Agaricales, Basidiomycotina): Flammulina. - Mycoscience 40: 411-426.

[78] PKB (Plantwise Knowledge Bank, http://www.plantwise.org/KnowledgeBank/Datasheet.aspx?dsid=7002)

[79] Pozdnyakova N.N., Nikiforova S.V., Makarov O.E., Turkovskaya O.V. (2010): Effect of polycyclic aromatic hydrocarbons on laccase production by white rot fungus Pleurotus ostreatus D1. -Applied Biochemistry and Microbiology 47(5): 543-548.

[80] Qin G.-F., Zhao J., Korhonen K. (2007): A study on intersterility groups of Armillaria in China. - Mycologia 99(3): 430-441.

[81] Ranadive K.R.,Vaidya J.G., Jite P.K., Ranade V.D., Bhosale S.R., Rabba A.S., Hakimi M., Deshpande G.S., Rathod M.M., Forutan A., Kaur M., Naik-Vaidya C.D., Bapat G.S., Lamrood P. (2011): Checklist of Aphyllophorales from the Western Ghats of Maharashtra state, India. - Mycosphere 2(2): 91-114.

[82] Rees B.J., Strid A. (2001): Relationships between Australian and Northern hemisphere Gymnopilus species 1: new spcies and common misconceptions regarding earlier names. - Australasian Mycologist 20(1): 21-48.

[83] Rigas F., Dritsa V. (2006): Decolorization of a polymeric dye by selected fungal strains in liquid cultures. - Enzyme and Microbial Technology 39: 120-124.

[84] Robinson T., Chandran B., Nigam P. (2001): Studies on the decolourisation of an artificial textile-effluent by white-rot fungi in N-rich and N-limited media. - Applied Microbiology and Biotechnology 57: 810-813.

[85] Robinson T., Nigam P.S. (2008): Remediation of textile dye waste water using a whiterot fungus Bjerkandera adusta through solid state fermentation (SSF). - Applied Biochemistry and Biotechnology 151: 618-628.

[86] Ryu S.H., Lee A.Y., Kim M. (2008): Molecular characteristics of two laccase from basidiomycete fungus Polyporus brumalis. - The Journal of Microbiology 46(1): 62-69.

[87] Ryvarden L., Gilbertson R.L. (1993, 1994): European Polypores, Vol I and Vol II. Fungiflora, Oslo.

[88] Sankaran K.V., Bridge P.D., Gokulapalan C. (2005): Ganoderma diseases of perennial crops in India-an overview. - Mycopathologia 159: 143- 152. 
[89] Simone D., Annesi T. (2012): Occurrence of Ganoderma adspersum on Pinus pinea. Phytopathologia Mediterranea 51(2): 374- 382.

[90] SIPMP (State Integrated Pest Management Program, University of California, http://ipm.ucanr.edu/index.html)

[91] Smith A.H., Hessler L.R. (1968): The North American species of Pholiota. - Hafner Publishing Company, New York.

[92] Steffen K.T., Schubert S., Tuomela M., Hatakka A., Hofrichter M. (2007): Enhancement of bioconversion of high-molecular mass polycyclic aromatic hydrocarbons in contaminated non-sterile soil by litter-decomposing fungi. - Biodegradation 18: 359-369.

[93] Stoytchev I., Nerud F. (2000): Ligninolytic enzyme complex of Armillaria spp. - Folia Microbiologica 45(3): 248-250.

[94] Šušla M., Novotný Č., Svobodová K. (2007): The implication of Dichomitus squalens laccase isoenzymes in dye decolorization by immobilised fungal culture. - Bioresource Technology 98: 2109-2115.

[95] Szczepkowski A. (2007): Macromycetes in the dendrological Park of the Warsaw Agricultural University. - Acta Mycologica 42(2): 179- 186.

[96] Tinoco R., Verdin J., Vasquez-Duhalt R. (2007): Role of oxidizing mediators and tryptophan 172 in the decoloration of industrial dyes by the versatile peroxidase from Bjerkandera adusta. - Journal of Molecular Catalysis B: Enzymatic 46: 1- 7.

[97] Tomšovsky M., Homolka L. (2003): Laccase and other ligninolytic enzyme activities of selected strains of Trametes spp. from different localities and substrates. - Folia Microbiologica 48(3): 413-416.

[98] Ungureanu C., Balaeș T., Favier L., Tănase C., Bahrim G. (2015): White-rot fungus implications in clofibric acid biodegradation. - Romanian Biotechnological Letters 20(3): 10388-10395.

[99] Vaithanomsat P., Chedchant J., Kreetachat T., Kosugi A., Apiwatanapiwat W., Thanapase W., Chuntranuluck S., Mori Y. (2012): Improvement of lignin-degrading enzymes production from the white-rot fungus (Lentinus strigosus) and its application in synthetic dye removal. - African Journal of Microbiology Research 6(1): 137- 148.

[100] Valderrama B., Oliver P., Medrano-Soto A., Vazquez-Duhalt R. (2003): Evolutionary and structural diversity of fungal laccases. - Antonie van Leeuwenhoek 84: 289-299.

[101] Valentiin L., Kluczek-Turpeinen B., Oivanen P., Hatakka A., Steffen K., Tuomela M. (2009): Evaluation of basidiomycetous fungi for pretreatment of contaminated soil. Journal of Chemical Technology and Biotechnology 84: 851-858. 